\title{
Sorption capacity of phosphate in mineral soils II Dependence of sorption capacity on soil properties
}

\author{
RAINA NISKANEN \\ University of Helsinki, Department of Agricultural Chemistry, \\ SF-00710 Helsinki, Finland
}

\begin{abstract}
The dependence of the indicator of phosphate sorption capacity on extractable $\mathrm{Al}$ and $\mathrm{Fe}$ and other soil properties was studied in a material consisting of 102 mineral soil samples. The sum of $\mathrm{P}$ adsorbed on soil during two days from a solution containing $\mathrm{P} 5 \mathrm{mmol} / \mathrm{l}$ and $\mathrm{P}$ extracted by $0.02 \mathrm{M}$ EDTA $(\mathrm{pH} \mathrm{5.3)}$ as an estimate of the initial $\mathrm{P}$ content in the soil was used as the indicator of $\mathrm{P}$ sorption capacity.

In clay and silt soils $(\mathrm{n}=51)$, the $\mathrm{Al}$ and $\mathrm{Fe}$ extracted by $0.05 \mathrm{M}$ oxalate $(\mathrm{pH} 2.9)$ together with the organic $\mathrm{C}$ content explained $85 \%$, the $\mathrm{Al}$ and $\mathrm{Fe}$ extracted by $0.05 \mathrm{M} \mathrm{K}_{4} \mathrm{P}_{2} \mathrm{O}_{7}(\mathrm{pH} 10)$ together with the clay content $87 \%$, the $\mathrm{Al}$ and Fe extracted by $0.02 \mathrm{M}$ EDTA (pH 5.3) $91 \%$, and the $\mathrm{Al}$ extracted by $1 \mathrm{M} \mathrm{CH}_{3} \mathrm{COONH}_{4}(\mathrm{pH} 4.8)$ together with the organic $\mathrm{C}$ and clay contents $78 \%$ of the variation of the indicator of phosphate sorption capacity. In coarse soils $(\mathrm{n}=51)$, the variation of the indicator was explained well only by oxalate-extractable metals, which together with soil $\mathrm{pH}$ and clay content explained $80 \%$ of the variation. Extractable Al was generally the most important explainer of variation. The results suggest that forms of extractable $\mathrm{Al}$ and $\mathrm{Fe}$ explaining the variation of the indicator of $\mathrm{P}$ sorption capacity in clay and silt soils are partially different from those in coarse soils.
\end{abstract}

Index words: acetate-extractable $\mathrm{Al}$, EDTA-extractable $\mathrm{Al}, \mathrm{Fe}$ and $\mathrm{P}$, oxalate-extractable $\mathrm{Al}$ and $\mathrm{Fe}$, pyrophosphateextractable $\mathrm{Al}$ and $\mathrm{Fe}$, soil $\mathrm{pH}$, clay content, organic carbon content

\section{Introduction}

In the previous paper (NISKANEN 1990), the phosphate sorption capacity of some mineral soils was estimated by means of sorption isotherms. When sorption properties of large soil material are to be studied, it is, however, laborious to determine complete sorption curves. BaCHE and Williams (1971) proposed the use of a single value sorption index to characterize the phosphate sorption properties of soil. Sorption determined from only one concentration may, however, be unsatisfactory if the initial phosphate content in soil is high (BARRow 1978). In such cases it may be valid to correct the sorption results by ad- 
ding an estimate of the initial P content. The aim of this paper was to study the dependence of the corrected indicator of $\mathrm{P}$ sorption capacity, determined by the one-point method, on extractable $\mathrm{Al}$ and $\mathrm{Fe}$ and other soil properties.

\section{Material and methods}

The material consisted of 51 clay or silt soils and 51 coarse soil samples, which have been presented more thoroughly in a previous paper (NISKANEN 1989) (Table 1). The samples were air-dried at room temperature and ground to pass through a 2 -mm sieve. The $\mathrm{pH}$ of the soil was measured in a soil- $0.01 \mathrm{M}$ $\mathrm{CaCl}_{2}$ suspension $(1: 2.5)$ (RYTI 1965). The particle-size distribution of inorganic matter was determined by the pipette method (ELoNEN 1971), the organic carbon content by the Alten wet combustion method (Graham 1948). Soil aluminium and iron were extracted by the following methods (NISKANEN 1989): $0.05 \mathrm{M}$ oxalate $(\mathrm{pH} 2.9$, ratio $1: 20 \mathrm{w} / \mathrm{v}$, shaking time $2 \mathrm{~h}$ ), $0.05 \mathrm{M} \mathrm{K}_{4} \mathrm{P}_{2} \mathrm{O}_{7}(\mathrm{pH} \mathrm{10,1:100}$ $\mathrm{w} / \mathrm{v}, 3 \mathrm{~h}$ ) and $0.02 \mathrm{M} \mathrm{Na}_{2}$-EDTA (pH 5.3, $1: 50 \mathrm{w} / \mathrm{v}, 3 \mathrm{~h}$ ). Aluminium was additionally extracted by $1 \mathrm{M}$ ammonium acetate $(\mathrm{pH} \mathrm{4.8,}$ $1: 10 \mathrm{w} / \mathrm{v}, 2 \mathrm{~h})($ McLean et al. 1958). The metals contained in filtrated extracts were de- termined by atomic absorption spectrophotometry.

To determine the phosphate sorption, $5 \mathrm{~g}$ of soil was treated at $+20^{\circ} \mathrm{C}$ for two days with $100 \mathrm{ml}$ of solution containing $\mathrm{KH}_{2} \mathrm{PO}_{4}$ $5 \mathrm{mmol} / \mathrm{l}$. The ionic strength of the solution was 0.01 , adjusted with $\mathrm{KCl} 5 \mathrm{mmol} / \mathrm{l}$. To inhibit microbial activity, the solution contained $0.01 \% \mathrm{NaN}_{3}$. The suspensions were daily shaken for eight hours. At the beginning and the end of the experiment, the $\mathrm{pH}$ of the suspensions was measured. The phosphorus concentration in filtrates was determined by a modified molybdenum blue method (KAILA 1955). The amount of retained phosphate was calculated as the difference between the phosphate quantity present initially and that remaining in the supernatant. The experiment was carried out in triplicate.

Phosphorus extracted by $0.02 \mathrm{M} \mathrm{Na}_{2}$-EDTA and determined by the molybdenum blue method was used as the estimate of the initial phosphorus content in soil. The sum of retained and initial phosphate content was used as the indicator of the $\mathrm{P}$ sorption capacity of the soil.

\section{Results}

The phosphate concentration $(5 \mathrm{mmol} / \mathrm{l})$ used to determine the sorption of phosphate

Table 1. Soil characteristics.

\begin{tabular}{|c|c|c|c|c|c|c|}
\hline & \multicolumn{3}{|c|}{$\begin{array}{l}\text { Clay and silt soils } \\
\qquad(\mathrm{n}=51)\end{array}$} & \multicolumn{3}{|c|}{$\begin{array}{l}\text { Coarse soils } \\
\qquad(\mathrm{n}=51)\end{array}$} \\
\hline & $\bar{x}$ & s & range & $\overline{\mathrm{x}}$ & s & range \\
\hline $\mathrm{pH}\left(\mathrm{CaCl}_{2}\right)$ & 5.4 & 0.8 & $3.9-7.2$ & 5.2 & 1.0 & $3.5-7.3$ \\
\hline Organic $C, \%$ & 3.7 & 2.8 & $0.8-14.6$ & 2.8 & 2.2 & $0.6-12.3$ \\
\hline Clay $(<2 \mu \mathrm{m}), \%$ & 40 & 14 & $15-72$ & 8 & 8 & $1-28$ \\
\hline Silt $(2-20 \mu \mathrm{m}), \%$ & 33 & 13 & $6-61$ & 12 & 7 & $1-29$ \\
\hline Coarser fractions $(>20 \mu \mathrm{m}), \%$ & 28 & 14 & $7-61$ & 81 & 12 & $51-98$ \\
\hline Oxalate-extractable $\mathrm{Al} \mathrm{mmol} / \mathrm{kg}$ soil & 71 & 41 & $29-222$ & 81 & 55 & $11-249$ \\
\hline$m \quad n \quad \mathrm{Fe} \quad n \quad n$ & 102 & 42 & $32-202$ & 53 & 31 & $3-144$ \\
\hline Pyrophosphate-extractable $\mathrm{Al} \mathrm{mmol} / \mathrm{kg}$ soil & 38 & 50 & $4-243$ & 43 & 28 & $4-104$ \\
\hline $\mathrm{Fe}$ & 29 & 22 & $5-111$ & 19 & 15 & $4-77$ \\
\hline EDTA-extractable $\mathrm{Al} \mathrm{mmol} / \mathrm{kg}$ soil & 19 & 18 & $4-85$ & 16 & 11 & $2-61$ \\
\hline$" \quad \Rightarrow \quad \mathrm{Fe} \quad m \quad n$ & 17 & 11 & $2-46$ & 6 & 7 & $1-32$ \\
\hline Acetate-extractable $\mathrm{Al} \mathrm{mmol} / \mathrm{kg}$ soil & 8.4 & 10.5 & $0.2-48.9$ & 8.6 & 6.6 & $0.9-34.8$ \\
\hline
\end{tabular}


Table 2. Sorption of phosphate, $0.02 \mathrm{M} \mathrm{Na}_{2}$-EDTA-extractable phosphate and indicator of phosphate sorption capacity $(\mathrm{mmol} / \mathrm{kg}$ soil).

\begin{tabular}{|c|c|c|c|c|c|c|c|c|c|c|}
\hline & \multirow[b]{2}{*}{$\mathrm{n}$} & \multicolumn{3}{|c|}{ Sorption of $\mathrm{P}$} & \multicolumn{3}{|c|}{$\begin{array}{l}0.02 \mathrm{M} \mathrm{Na}_{2} \text {-EDTA- } \\
\text { extractable P }\end{array}$} & \multicolumn{3}{|c|}{$\begin{array}{c}\text { Indicator of } \mathrm{P} \\
\text { sorption capacity }\end{array}$} \\
\hline & & $\overline{\mathrm{x}}$ & s & range & $\overline{\mathrm{x}}$ & s & range & $\overline{\mathbf{x}}$ & s & range \\
\hline \multicolumn{11}{|c|}{ Clay and silt soils: } \\
\hline Surface soils & 27 & 28.7 & 20.2 & $7.8-81.8$ & 5.4 & 4.9 & $0.3-19.4$ & 34.1 & 18.5 & $12.7-82.3$ \\
\hline Subsoils & 24 & 27.1 & 19.5 & $9.9-86.7$ & 2.7 & 2.3 & $0.0-7.9$ & 29.8 & 18.6 & $12.7-87.2$ \\
\hline All & 51 & 28.0 & 19.7 & $7.8-86.7$ & 4.2 & 4.1 & $0.0-19.4$ & 32.1 & 18.5 & $12.7-87.2$ \\
\hline \multicolumn{11}{|l|}{ Coarse soils: } \\
\hline Surface soils & 26 & 16.6 & 11.3 & $-3.5-41.8$ & 3.1 & 3.1 & $0.2-13.6$ & 19.6 & 10.5 & $-0.3-42.6$ \\
\hline Subsoils & 25 & 16.5 & 13.5 & $-7.2-51.7$ & 0.9 & 1.2 & $0.0-5.3$ & 17.2 & 13.4 & $-6.4-52.1$ \\
\hline All & 51 & 16.3 & 12.6 & $-7.2-51.7$ & 2.0 & 2.6 & $0.0-13.6$ & 18.3 & 12.2 & $-6.4-52.1$ \\
\hline \multicolumn{11}{|l|}{ All soils: } \\
\hline Surface soils & 53 & 22.7 & 17.5 & $-3.5-81.8$ & 4.3 & 4.2 & $0.2-19.4$ & 27.0 & 16.7 & $-0.3-82.3$ \\
\hline Subsoils & 49 & 21.6 & 17.6 & $-7.2-86.7$ & 1.8 & 2.0 & $0.0-7.9$ & 23.3 & 17.4 & $-6.4-87.2$ \\
\hline
\end{tabular}

on experimental soils was the same as BACHE and Williams (1971) used in determination of the $\mathrm{P}$ sorption index. The initial $\mathrm{pH}$ of the soil suspensions was $4.0-6.6$ and after the sorption, lasting two days, the $\mathrm{pH}$ was slightly higher, the increase being no more than $0.5 \mathrm{pH}$ units. The experimental soils sorbed, on average, a little more than $20 \%$ of the added $\mathrm{P}(100 \mathrm{mmol} / \mathrm{kg}$ soil) (Table 2$)$. The sorption was higher in clay and silt soils than in coarser soils. The material consisted of 23 samples, mainly clay and silt soils, which adsorbed more than $30 \%$ of the added P. In all, 20 samples adsorbed less than $10 \%$ of added $\mathrm{P}$; these were mainly coarser soils. There were two coarser soil samples which released $P$ rather than adsorbed it.

The phosphorus extracted by EDTA was used as an estimate of the initial content of the adsorbed $\mathrm{P}$ in the soil (Table 2). EDTA extracted, on average, more $\mathrm{P}$ from surface soils than from subsoils, and more $\mathrm{P}$ from clay and silt soils than from coarser ones. In surface soils, the EDTA-extractable P seemed to increase with increasing $\mathrm{pH}\left(\mathrm{r}=0.68^{* * *}\right.$, $\mathrm{n}=53$ ). In surface layers of clay and silt soils, the correlation coefficient between extractable $\mathrm{P}$ and soil $\mathrm{pH}$ was $0.80^{* * * *}(\mathrm{n}=27)$. In coarse surface soils, the extractability of $\mathrm{P}$ increased with an increasing clay content $\left(\mathrm{r}=0.69^{* * *}\right.$, $\mathrm{n}=26$ ).
EDTA-extractable $\mathrm{P}$ is thought to be connected with inorganic $\mathrm{P}$ fractions in soil which are bound to aluminium and iron (ALEXAN. DER and ROBERTSON 1972) and also to calcium (Ahmed and Islam 1975, Sahrawat 1977, Hartikainen 1979). Several studies (Alexan. DER and ROBERTSON 1972, AHMEd and IsLam 1975, Olsen 1975, Sahrawat 1977, OnKen et al. 1980) verified that acidic EDTA solution extracts $\mathrm{P}$ which is available to plants.

The indicator of P sorption capacity (Table 2), which includes sorbed and EDTAextractable P, amounted, on average, to about $25 \mathrm{mmol} / \mathrm{kg}$ soil. The mean value of the indicator was higher in clay and silt soils than in coarser soils.

The dependence of the indicator of $\mathrm{P}$ sorption capacity on soil properties was studied by means of linear regression analysis. The variables were as follows:

$\mathrm{X}_{1}=$ indicator of $\mathrm{P}$ sorption capacity ( $\mathrm{mmol} / \mathrm{kg}$ soil)

$\mathrm{X}_{2}=$ extractable aluminium $(\mathrm{mmol} / \mathrm{kg}$ soil $)$

$\mathrm{X}_{3}=$ extractable iron ( $\mathrm{mmol} / \mathrm{kg}$ soil)

$\mathrm{X}_{4}=$ organic carbon content $(\%)$

$\mathrm{X}_{5}=$ soil pH

$\mathrm{X}_{6}=$ clay content $(\%)$

In clay and silt soils, oxalate-extractable aluminium and iron together with the organic carbon content explained $(\mathrm{P}=0.001) 85 \%$ of 
the variation of the indicator of $\mathrm{P}$ sorption capacity. The regression equation and partial correlation and $\beta$ coefficients were as follows:

$$
\begin{array}{cc}
\mathrm{X}_{1}=-8.13+0.293 \mathrm{X}_{2}+0.117 \mathrm{X}_{3}+2.01 \mathrm{X}_{4} \\
\mathrm{r}_{12.34}=0.74 * * * & \beta_{12.34}=0.64 \\
\mathrm{r}_{13.24}=0.56^{* * *} & \beta_{13.24}=0.27 \\
\mathrm{r}_{14.23}=0.46^{* * *} & \beta_{14.23}=0.31
\end{array}
$$

The content of oxalate-extractable $\mathrm{Al}$ explained $54 \%$, the content of iron $31 \%$ and the content of organic carbon $21 \%$ of the variation in sorption when the effect of the other two independent variables was eliminated.

Oxalate-extractable $\mathrm{Al}$ and $\mathrm{Fe}$, soil $\mathrm{pH}$ and clay content explained $(\mathrm{P}=0.001) 80 \%$ of the variation in the indicator of $\mathrm{P}$ sorption capacity in coarse soils, the regression equation being:

$$
\begin{array}{rll}
\mathrm{X}_{1}=-3.33+0.185 \mathrm{X}_{2}+0.094 \mathrm{X}_{3}-3.18 \mathrm{X}_{5}+0.32 \mathrm{X}_{6} \\
\mathrm{r}_{12.356}=0.87^{* * *} & \beta_{12.356}=0.84 \\
\mathrm{r}_{13.256}=0.43^{* *} & \beta_{13.256}=0.24 \\
\mathrm{r}_{15.236}=-0.44 * * & \beta_{15.236}=-0.25 \\
\mathrm{r}_{16.235}=0.32 * & \beta_{16.235}=0.20
\end{array}
$$

The content of oxalate-extractable $\mathrm{Al}$ explained $76 \%$, the content of Fe $19 \%$, the soil pH $19 \%$ and the clay content $11 \%$ of the variation when the effect of the other independent variables was eliminated. In both soil groups, oxalate-extractable $\mathrm{Al}$ was the most important explainer of the variation in the indicator of P sorption capacity.

Pyrophosphate-extractable $\mathrm{Al}$ and $\mathrm{Fe}$ together with clay content explained $(\mathrm{P}=0.001)$ $87 \%$ of the variation in the indicator of $\mathrm{P}$ sorption capacity in clay and silt soils according to the equation:

$$
\begin{array}{cc}
X_{1}=5.23+0.184 X_{2}+0.417 X_{3}+0.20 X_{6} \\
r_{12.36}=0.73 * * * & \beta_{12.36}=0.494 \\
r_{13.26}=0.73 * * * & \beta_{13.26}=0.488 \\
r_{16.23}=0.37 * * & \beta_{16.23}=0.150
\end{array}
$$

Pyrophosphate-extractable $\mathrm{Al}$ and $\mathrm{Fe}$ were equally important variables. Al explained $53 \%$, Fe $54 \%$ and the clay content $14 \%$ of the variation when the effect of the other two independent variables was eliminated. In coarse soils, pyrophosphate-extractable $\mathrm{Al}$ ex- plained $(\mathrm{P}=0.001) 47 \%$ of the variation in the indicator of $\mathrm{P}$ sorption capacity according to the equation: $X_{1}=5.98+0.300 X_{2}$.

EDTA-extractable $\mathrm{Al}$ and $\mathrm{Fe}$ explained $(\mathrm{P}=0.001) 91 \%$ of the variation in the indicator of $\mathrm{P}$ sorption capacity in clay and silt soils according to the equation:

$$
\begin{aligned}
& \mathrm{X}_{1}=8.57+0.844 \mathrm{X}_{2}+0.438 \mathrm{X}_{3} \\
& \mathrm{r}_{12.3}=0.92 * * * \beta_{12.3}=0.80 \\
& \mathrm{r}_{13.2}=0.60^{* * *} \beta_{13.2}=0.26
\end{aligned}
$$

$\mathrm{Al}$ was a more important independent variable than $\mathrm{Fe}$. Al explained $84 \%$ and $\mathrm{Fe} 36 \%$ of the variation in the indicator of $\mathrm{P}$ sorption capacity. In coarse soils, EDTA-extractable $\mathrm{Al}$ explained $(\mathrm{P}=0.01)$ only $20 \%$ of the variation according to the equation: $\mathrm{X}_{1}=10.18+0.508 \mathrm{X}_{2}$.

Acetate-extractable $\mathrm{Al}$ and the organic carbon and clay contents explained $(\mathrm{P}=0.001)$ $78 \%$ of the variation in the indicator of $\mathrm{P}$ sorption capacity in clay and silt soils according to the regression equation:

$$
\begin{array}{ccrl}
X_{1}=5.50+0.859 X_{2} & +0.272 X_{4}+0.24 X_{6} \\
r_{12.46} & =0.81 * * * & & \beta_{12.46}=0.49 \\
r_{14.26} & =0.55^{* * *} & \beta_{14.26}=0.41 \\
r_{16.24} & =0.34 * & \beta_{16.24}=0.18
\end{array}
$$

$\mathrm{Al}$ explained $65 \%$, the organic carbon content $30 \%$ and the clay content $12 \%$ of the variation when the effect of the other two independent variables was eliminated. In coarse soils, acetate-extractable $\mathrm{Al}$ explained $(\mathrm{P}=0.001) 36 \%$ of the variation in the indicator according to the equation: $\mathrm{X}_{1}=8.75+$ $1.112 \mathrm{X}_{2}$.

\section{Discussion}

In the present soil material, $\mathrm{Al}$ and $\mathrm{Fe}$ explained the variation of the indicator of $\mathrm{P}$ sorption capacity. Aluminium was generally a more important explainer than iron. In numerous papers concerning the dependence of the $\mathrm{P}$ sorption on soil properties (e.g. Williams et al. 1958, Kaila 1959, 1963, Bromfield 1964, 1965, Saini and MacLean 1965, AhenKORAH 1968, LoPEZ-HERnANDEZ and Burnham 
1973, 1974, HartiKaINEN 1979, WADA and GUNJIGAKE 1979), extractable aluminium has been more important than iron in explaining the retention of $\mathrm{P}$. In sorption studies, the Freundlich constant $\mathrm{k}$, the anion exchange capacity (PIPER 1944) and the P sorption index (BACHE and Williams 1971) are used as indicators of $\mathrm{P}$ sorption capacity, and metals are extracted by oxalate, dithionite, $\mathrm{HCl}$, ammonium acetate and acetic acid solutions. In the study of KAILA (1963), oxalate-extractable Al and Fe explained nearly $80 \%$ of the variation of the Freundlich constant $\mathrm{k}$ in clay soils and about $60 \%$ in coarse soils. The partial correlation coefficient for the relationship between $\mathrm{k}$ and $\mathrm{Al}$ was $0.78^{* * *}(\mathrm{n}=151)$ in clay soils and $0.63^{* * *}(\mathrm{n}=109)$ in coarse soils, and for the relationship between $\mathrm{k}$ and $\mathrm{Fe} 0.46^{* * *}$ in clay soils and $0.30^{* * *}$ in coarse soils. KAILA's results show the same tendency as those obtained in the present investigation.

In some cases iron has been found to be a more important explainer of $\mathrm{P}$ sorption than aluminium (KAILA 1963, BROMFIELD 1965, Ahenkorah 1968, Lopez-Hernandez and Burnham 1973, 1974). In these studies, however, $\mathrm{Al}$ is often extracted by a different method than Fe. According to Lopez-HerNANDEZ and Burnham (1973), extractable Al and $\mathrm{Fe}$ explain the sorption of $\mathrm{P}$ the better the more efficient the extraction method of metals is.

The greater significance of soil aluminium than soil iron in the adsorption of phosphate may be related partially to the different way these metals occur in soil. Iron oxides and hydroxides are generally present as discrete mineral particles, even when they are present on surfaces of clay minerals (DESHPANDE et al. 1964, Greenland et al. 1968). Aluminium hydroxides tend to form films over clay particles (El Swaify and EMERSon 1975), offering a large surface area for phosphate sorption. In the present study the significance of a larger sorption surface was manifested by the higher sorption of phosphate in clay and silt soils than in coarse soils.

In this study, the organic carbon content explained the variation of the indicator of $\mathrm{P}$ sorption capacity in clay and silt soils. In many earlier papers, $\mathrm{P}$ sorption has been found to depend on the content of organic matter in soil (WILliams et al. 1958, SAINI and MacLean 1965, Ahenkorah 1968, LopezHernandez and Burnham 1974). This indicates that active $\mathrm{Al}$ and $\mathrm{Fe}$ are closely connected with soil organic matter, which retards the crystallization of oxides and thus enhances their activity in sorption (WILliams et al. 1958, Schwertmann et al. 1968). In coarse soils of the present material, $\mathrm{pH}$, clay content and oxalate-extractable Fe were about equally important explainers of the variation in the indicator of $\mathrm{P}$ sorption capacity. In most of the previously mentioned studies, the dependence of the indicator of $\mathrm{P}$ sorption on soil $\mathrm{pH}$ and clay content is weak or insignificant.

The present study showed that the forms of extractable $\mathrm{Al}$ and $\mathrm{Fe}$ explaining the variation of the indicator of $\mathrm{P}$ sorption capacity in clay and silt soils are partially different from those of coarse soils. In clay and silt soils, the variation of the indicator was rather well explained by the metals extracted by all of the methods studied, whereas in coarse soils, the variation in the indicator of $\mathrm{P}$ sorption capacity was explained well only by oxalate-extractable metals. In clay and silt soils, the indicator of P sorption capacity, in particular, seemed to be related to the EDTA-extractable metals, whereas in coarse soils this fraction of metals explained the variation in $\mathrm{P}$ retention only weakly. It has been mentioned before that particularly in clay soils, $\mathrm{Al}$ hydroxides occur as films on clay particles, thus providing large surface for retention of P. It may be that EDTA extracted such hydroxide films, whereas EDTA was able to extract only poorly the more crystalline forms, which may constitute a considerable proportion of the $\mathrm{P}$ retaining material in coarse soils. 


\section{References}

Ahenkorah, Y. 1968. Phosphorus-retention capacities of some cocoa-growing soils of Ghana and their relationship with soil properties. Soil Sci. 105: 24-30.

Aнмed, B. \& Islam, A. 1975. The use of sodium EDTA as an extractant for determining available phosphate in soil. Geoderma 14: 261-265.

Alexander, T.G. \& Robertson, J.A. 1972. EDTA extractable phosphorus in relation to available and inorganic phosphorus forms in soils. Soil Sci. 114: $69-72$.

BACHE, B.W. \& Williams, E.G. 1971. A phosphate sorption index for soils. J. Soil Sci. 22: 289-301.

Barrow, N.J. 1978. The description of phosphate adsorption curves. J. Soil Sci. 29: 447-462.

Bromfield, S.M. 1964. Relative contribution of iron and aluminium in phosphate sorption by acid surface soils. Nature 201: 321-322.

- 1965. Studies of the relative importance of iron and aluminium in the sorption of phosphate by some Australian soils. Aust. J. Soil Res. 3: 31-44.

Deshrande, T.L., Greenland, D.J. \& Quirk, J.P. 1964. Role of iron oxides in the binding of soil particles. Nature 201: 107-108.

Elonen, P. 1971. Particle-size analysis of soil. Acta Agr. Fenn. 122: 1-122.

El. Swalfy, S.A. \& Emerson, W.W. 1975. Changes in physical properties of soil clays due to precipitated aluminium and iron hydroxides: I. Swelling and aggregate stability after drying. Soil Sci. Soc. Am. Proc. 39: 1056-1063.

Graham, E.R. 1948. Determination of soil organic matter by means of a photoelectric colorimeter. Soil Sci. 65: $181-183$.

Greenland, D.J., Oades, J.M. \& Sherwin, J.W. 1968. Electron microscope observations of iron oxides in some red soils. J. Soil Sci. 19: 116-122.

Hartikainen, H. 1979. Phosphorus and its reactions in terrestrial soils and lake sediments. J. Scient. Agric. Soc. Finl. 51: 537-624.

KAlLA, A. 1955. Studies on the colorimetric determination of phosphorus in soil extracts. Acta Agr. Fenn. 83: 25-47.

- 1959. Retention of phosphate by peat samples. J. Scient. Agric. Soc. Finl. 31: 215-225.

- 1963. Dependence of the phosphate sorption capacity on the aluminium and iron in Finnish soils. J. Scient. Agric. Soc. Finl. 35: 165-177.
Lopez-Hernandez, I.D. \& Burnham, C.P. 1973. Extraction methods for aluminium and iron in relation to phosphate adsorption. Commun. Soil Sci. Pl. Anal. 4: 9-16.

- \& Burnham, C.P. 1974. The covariance of phosphate sorption with other soil properties in some British and tropical soils. J. Soil Sci. 25: 196-206.

Mclean, E.O., Heddleson, M.R., Bartlett, R.J. \& Holowayshuk, N. 1958. Aluminum in soils: I. Extraction methods and magnitudes in clays and Ohio soils. Soil Sci. Soc. Proc. 22: 382-387.

Niskanen, R. 1989. Extractable aluminium, iron and manganese in mineral soils. III Comparison of extraction methods. J. Agric. Sci. Finl. 61: 89-97.

- 1990. Sorption capacity of phosphate in mineral soils. I Estimation of sorption capacity by means of sorption isotherms. J. Agric. Sci. Finl. 62: 1-8.

OLSEN, R.A. 1975. Rate of dissolution of phosphate from minerals and soils. Soil Sci. Soc. Amer. Proc. 39: $634-639$.

Onken, A.B., Matheson, R. \& Williams, E.J. 1980. Evaluation of EDTA-extractable phosphorus as a soil test procedure. Soil Sci. Soc. Amer. J. 44: 783-786.

PiPer, C.S. 1944. Soil and plant analysis. 368 p. New York.

RYTI, R. 1965. On the determination of soil pH. J. Scient. Agric. Soc. Finl. 37: 51-60.

Sahrawat, K.L. 1977. EDTA extractable phosphorus in soils as related to available and inorganic phosphorus forms. Commun. Soil Sci. Pl. Anal. 8: 281-287.

SaINI, G.R. \& MacLean, A.A. 1965. Phosphorus retention capacities of some New Brunswick soils and their relationship with soil properties. Can. J. Soil Sci. 45: 15-18.

Schwertmann, U., Fischer, W.R. \& Papendorf, H. 1968. The influence of organic compounds on the formation of iron oxides. Trans. 9th Int. Cong. Soil Sci. 1: $645-655$.

WADA, K. \& GUNJIGAKE, N. 1979. Active aluminum and iron and phosphate adsorption in Ando soils. Soil Sci. 128: $331-336$.

Williams, E.G., Scott, N.M. \& MeDonald, M.J. 1958. Soil properties and phosphate sorption. J. Sci. Food Agric. 9: 551-559.

Ms received June 8, 1989 


\section{SELOSTUS}

\section{Kivennäismaiden fosfaatin pidätyskapasiteetti \\ II Pidätyskapasiteetin riippuvuus maan ominaisuuksista}

\section{Raina Niskanen}

Maanviljelyskemian laitos, Helsingin yliopisto, 00710 Helsinki

Kivennäismaiden $(\mathrm{n}=102)$ fosfaatin pidătyskapasiteetin riippuvuutta uuttuvan alumiinin ja raudan pitoisuuksista ja muista maan ominaisuuksista tutkittiin käyttäen fosfaatin pidätyskapasiteetin indikaattorina kahdessa vuorokaudessa maahan pidättyneen (reaktioliuoksessa P 5 mmol/l) ja maassa ennestään olevan, 0,02 M EDTA:lla $(\mathrm{pH} 5,3)$ uuttuvan, fosfaatin summaa.

Savi- ja hiesumaissa $(n=51)$ maan ominaisuudet selittivăt melko hyvin fosfaatin pidătyskapasiteetin indikaattorin vaihtelua. Selitysaste oli $85 \%$, kun selittävinả muuttujina olivat $0,05 \mathrm{M}$ oksalaatilla ( $\mathrm{pH} 2,9$ ) uuttuva alumiini ja rauta sekả orgaanisen hiilen pitoisuus. Kun selittăvină muuttujina olivat $0,05 \mathrm{M}$ kaliumpyrofosfaatilla $(\mathrm{pH} 10)$ uuttuva alumiini ja rauta sekä saveksen pitoisuus, seli- tysaste oli 87 \%. 0,02 M EDTA:lla (pH 5,3) uuttuva alumiini ja rauta selittivăt $91 \%$ ja $1 \mathrm{M}$ ammoniumasetaatilla $(\mathrm{pH} \mathrm{4,8)}$ uuttuva alumiini sekă orgaanisen hiilen ja saveksen pitoisuus $78 \%$ fosfaatin pidätyskapasiteetin indikaattorin vaihtelusta. Karkeissa maissa $(n=51)$ ainoastaan oksalaattiuuttoinen alumiini ja rauta selittivăt hyvin pidătyskapasiteetin indikaattorin vaihtelua, yhdessä maan pH:n ja saveksen pitoisuuden kanssa ne selittivăt $80 \%$ vaihtelusta. Molemmissa maaryhmissă uuttuva alumiini oli yleensả tărkeämpi selittäjă kuin uuttuva rauta. Tulokset osoittavat, että fosfaatin sorptiokapasiteetin indikaattorin vaihtelua selittävä alumiini ja rauta olivat savi- ja hiesumaissa uuttuvuudeltaan osittain erilaisia kuin karkeissa maissa. 